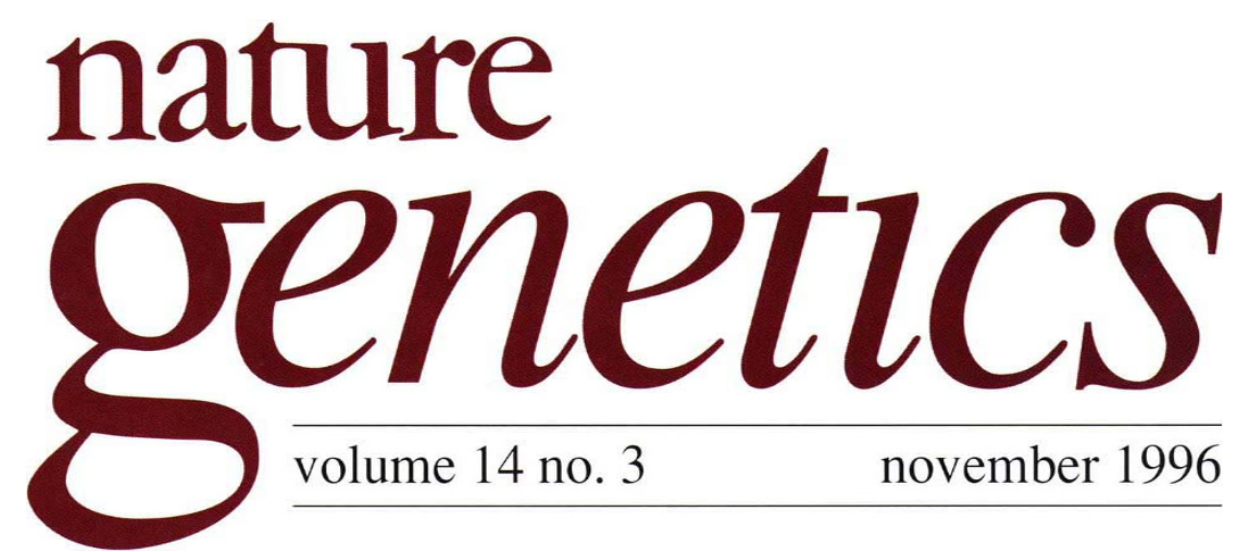

\title{
What are genes for?
}

This month's issue of Nature Genetics contains reports documenting the identification of no fewer than five genes which, when defective, are responsible for important genetic disorders ranging from progressive neurodegeneration to chromosome instability, and abnormal pigmentation to developmental abnormalities. As the pace with which genes are tied to genetic diseases quickens, it is appropriate to ponder just what these discoveries actually mean, and whether news of them is disseminated in a responsible fashion. Take, for example, the stern remarks of Horace Freeland Judland in the revised edition of his classic text, The Eighth Day of Creation (Cold Spring Harbor Laboratory Press; 1996), which John Maddox (in the book's preface) praises as 'a monumental piece of scholarship that will be read and referred to as long as there is science.' Judland condemns the frequent use by the press of 'the fallacious phrase "the gene for" some disease or defect' as simplistic and dangerous, a manifestation of the selling of the genome project. He writes:

It is announced that molecular biologists have discovered the gene for schizophrenia. The gene for diabetes. The gene for alcoholism. The gene for Huntington's chorea. The gene for homosexuality. The gene for Alzheimer's disease. Another gene for schizophrenia. The gene for obesity. Another gene for pancreatic cancer (did you miss the first one?) The gene for vivacity. With honorable exceptions, specialists have failed clearly and insistently to convey certain of the elements of genetics to the media and to the public through them - and cannot pass the blame to the sensationalism of journalists of the ignorance of that public.

(Apologies in advance, then, if the brief summaries of the new reports fall into the same trap.) Beginning on page 269 , three groups describe the pattern of trinucleotide repeat expansion in the gene for spinocerebellar ataxia (SCA) type $2-$ the third defective SCA gene to be identified ${ }^{1-3}$. The SCA2 gene was cloned in three contrasting ways, with arguably the most interesting being the new method devised by Tsuji and colleagues ${ }^{2}$ termed DIRECT (for 'direct identification of repeat expansion and cloning technique'). This method offers a potentially powerful means of isolating other genes harbouring expanded triplet repeats present not only in neurodegenerative diseases, but perhaps some cases of more common psychiatric disorders as well. Also in this issue, two groups have isolated the gene for the most common form of Fanconi anaemia (FA), an early-onset disorder characterized by chromosomal instability and haematologic abnormalities (pages $320,324)^{4,5}$. This gene for group A is considered 'enigmatic' - a tactful way of 
1. Pulst, S.M. et al. Nature Genet. 14, 269-276 (1996).

2. Sanpei, K. et al. Nature Genet. 14, 277-284 (1996).

3. Imbert, G. et al. Nature Genet. 14, 285-291

4. Lo Ten Foo, J.P. et al. Nature Genet. 14, 320-323 (1996).

5. The Fanconi Anaemia/Breast Cancer Consortium. Nature Genet. 14, 324-328 (1996). 6. Strathdee, C. et al. Nature 356, 763-767 (1992) 7. Oh, J. et al. Nature Genet. 14, 300-306 (1996). 8. Nagle, D. et al. Nature Genet. 14, 307-311 (1996).

Perou, C.M. et al. Nature Genet. 13, 303-308 (1996).

0. Barbosa, M.D.F.S. et al. Nature 382, 262-265 (1996).

11. Hoglund, P. et al. Nature Genet. 14, 316-319 (1996).

2. Belloni, E. et al. Nature Genet. 14, 353-358 (1996).

13. Roessler, E. et al. Nature Genet. 14, 357-360 (1996).

14. Joutel, A. et al. Nature (in the press). acknowledging that there are few clues to its function, although in contrast to the group $\mathrm{C}$ gene product $(\mathrm{FAC})^{6}, \mathrm{FAA}$ appears to reside in the nucleus and might form part of a pathway monitoring chromosomal integrity.

On page 300, Richard Spritz and colleagues report the identification of the gene for Hermansky-Pudlak syndrome (HPS) ${ }^{7}$, which is characterized by albinism and haematological problems stemming from abnormalities in platelet dense bodies, lysosomes and melanosomes. The errant gene probably encodes a transmembrane protein that might interact with the product of the gene for a related disorder Chediak-Higashi syndrome (CHS). On page 307, Karen Moore and colleagues present the complete sequence of the $C H S$ gene ${ }^{8}$, removing doubts created recently when two groups reported distinct but non-overlapping portions of the same gene $^{9,10}$. Another transmembrane protein is shown by Juha Kere's group to be at fault in patients with congenital chloride diarrhea (page 316$)^{11}$.

Finally, two papers ${ }^{12,13}$ show that disruption of the human homologue of Sonic Hedgehog (SHH) results in the developmental disorder known as holoprosencephaly (HPE) (pages 353, 357). The groups of Lap-Chee Tsui and Steve Scherer in Toronto, and Max Muenke in Philadelphia, characterized a small critical region on chromosome $7 \mathrm{q} 36$ containing a cluster of translocation breakpoints and overlapping deletions, incriminating the $S H H$ gene. The clincher comes in the second paper - five mutations recorded in HPE patients from five families with autosomal dominant transmission of the disease.

For the clinic or for science? While exciting and gratifying, these findings do not (immediately) change the fact that our understanding of gene function is hopelessly naive in most instances. Judland argues that to equate newly discovered genes simply with a genetic disorder is a disastrous oversimplification: to refer to a gene as being 'for' disease $\mathrm{X}$ ignores the fact that, in its native form, the gene has a totally different role. If Judland had his way, newspaper headlines might read: "SCIENTISTS IDENTIFY SEGMENT POLARITY ALLELOMORPH UNDERLYING ABERRANT HUMAN DEVELOPMENT", instead of announcing (as some might) that they had uncovered the 'gene for holoprosencephaly.' As has been evident since the days of Thomas Hunt Morgan, genes act in concert, and disrupting one gene can have manifold effects on the development of an organism. In an ideal world, scientists would be able to communicate such subtleties to the public and avoid unnecessarily raising expectations, as claims to have discovered 'the gene for breast cancer' undoubtedly did in some quarters. Judland is fighting a losing battle here, and he knows it, just as "we cannot restore the word "gay" to mean debonair, joyous, again.'

While the clinical consequences for new genetic discoveries assuredly take precedence in the public consciousness, it should not be ignored that these studies carry important implications for biology as a whole. The human Sonic Hedgehog papers are a case in point: with the recent demonstration of mutations in other familiar Drosophila gene homologues, such as the Patched gene in nevoid basal cell carcinoma and Notch3 in a rare familial form of stroke and dementia (known as CADASIL) ${ }^{14}$, human genetics is starting to make exciting contributions to developmental biology. The growing interest in Fanconi anaemia also reflects an awareness identifying these genes will provide new leads in the area of haematopoiesis. Having said that, most patients with Fanconi anaemia or Hermansky-Pudlak syndrome are not going to be overly concerned whether their errant genes encode a piece of the DNA repair machinery or a component of a vesicular trafficking pathway. The hope that these newsworthy events instill in patients and their families for treating and perhaps conquering disease is enormously beneficial, even if occasionally overblown. The day these genetic discoveries pay off will be worth waiting for. 